PRODUCTION

ENGINEERING
2015, Vol. 6, No 1, pp 26-29

ISSN 2353-5156

ISSN 2353-7779 (print version)

(online version)

ARCHIVES

Article history: Received: 16.12.2014 Accepted: 08.01.2015 Online: 31.03.2015

\title{
Reparation of damaged forging dies by hard facing (HF) technology
}

\author{
Vukić Lazić ${ }^{1}$, Dušan Arsić ${ }^{2}$, Ružica R. Nikolić ${ }^{1,3}$, Srbislav Aleksandrović ${ }^{1}$, Dragan Milosavljević ${ }^{1}$, Milan \\ Djordjević ${ }^{2}$, Rajko Čukić ${ }^{4}$
}

${ }^{1}$ Professor, PhD Faculty of Engineering, University of Kragujevac, Serbia

${ }^{2}$ Research associate, MS Faculty of Engineering, University of Kragujevac, Serbia

${ }^{3}$ Senior resercher, PhD Research center, University of Žilina, Univerzitna 1, 01026 Žilina, Slovakia

${ }^{4}$ Assitant Professor, PhD Faculty of Engineering, University of Kragujevac, Serbia

ruzicarnikolic@yahoo.com

\begin{abstract}
The forging dies are in exploitation exposed to elevated temperatures and variable impact loads, both compressive and shear. Steels for manufacturing of these tools must endure those loads while maintaining mechanical properties and being resistant to wear and thermal fatigue. For those reasons, the alloyed steels are used for making the forging dies, though they have less weldability, because alloying increases proneness to hardening. Any reparatory hard facing (HF) of the damaged dies would require the specially adjusted technology to the particular piece. In this paper reparatory hard facing of dies used for forging pieces in the automobile industry is considered. Prior to reparatory hard facing of the real tools, numerous experimental hard facings on models were performed. All the model hard facings were done on the same steels which were used for production of the real forging dies. To define the optimal hard facing technology one needs to derive the optimal combination of the adequate heat treatment(s), to select the proper filler metals and the welding procedure. The established optimal HF technology was applied to real forging dies whose service life was further monitored in conditions of exploitation.
\end{abstract}

Key words: Forging dies, hard facing (HF), filler metals (FM), hardness, microstructure.

\section{Introduction}

Problems related to reparatory hard facing (HF) of damaged forging dies, which are subjected to heating up to extremely high temperatures, are considered in this paper. Steels aimed for production of such tools ought to sustain high impact loads, to maintain the good mechanical properties, to be resistant to wear and thermal fatigue (ABACHI S. et al. 2010, CHOI C. et a. 2012, EBARA R. and Kubota K. 2008, LAVTAR L. et al. 2005, SUMMERVILE E. et al. 1995). Factors that lead to thermal fatigue are: thermo-physical and mechanical material properties and the piece geometry (MARKOVIĆ S. et al. 2011, LAZIĆ V. et al. 2009, LAZIĆ V. et al. 2011). Due to all those reasons, alloyed steels are used, despite their poor weldability. This is why any reparation by the HF procedure requires specially prescribed technology, adjusted for the particular working piece. Besides the optimal HF technology, it is necessary to define the corresponding heat treatment (MUTAVDŽIĆ M., et al. 2012). Resulting welds, obtained after the HF, were tested in order to establish the hardness distribution in some zones and the microstructure of the HF layer, heat affected zone (HAZ) and the base metal (BM) (MUTAVDŽIĆ M. et al. 2008).

In this case, forging dies for manufacturing parts in the automobile and truck industries were analyzed. During the extensive monitoring of those tools in exploitation, it was noticed that failures could be caused by an increase in dimensions of the forged pieces due to die wearing, deformation of the certain portions of the die, appearance of the cracks and local fractures. Those damages could be repaired by using 
the MMAW method for HF, followed by grinding or milling. A change of hardness and structure in applied welds, namely in the heat affected zone (HAZ) below the weld, was adopted as the quality criterion of executed HF layers.

\section{Properties of used materials}

Steels for work at elevated temperatures operate at temperatures higher than $300{ }^{\circ} \mathrm{C}$. For manufacturing of forging dies, most frequently applied steels are: $\breve{C} 5742$ (56 NiCrMoV7) and Č4751 (X38CrMoV51). These two steels, whose chemical composition and mechanical properties are given in table 1 (Catalogues and Prospects 2013), were used in all the experiments.

Table 1. Chemical composition, mechanical properties and microstructure of applied steels

\begin{tabular}{|c|c|c|c|c|c|c|c|c|c|c|}
\hline \multirow{2}{*}{ No. } & \multirow{2}{*}{$\begin{array}{l}\text { Mark } \\
\text { (JUS) }\end{array}$} & \multicolumn{9}{|c|}{ Chemical composition, \% } \\
\hline & & C & $\mathrm{Si}$ & Mr & $\mathbf{P}$ & $\mathrm{S}$ & $\mathbf{C r}$ & $\mathrm{Ni}$ & Mo & $\mathbf{V}$ \\
\hline 1. & $\check{C} 5742$ & 0.55 & 0.3 & 0.7 & 0.03 & 0.03 & 1.1 & 1.7 & 0.5 & 0.12 \\
\hline 2. & $\check{C} 4751$ & 0.40 & 1.0 & 0.4 & 0.02 & 0.02 & 5.0 & - & 1.3 & 0.4 \\
\hline \multicolumn{11}{|c|}{ Mechanical properties and microstructure of applied steels } \\
\hline \multirow[b]{2}{*}{ No. } & \multirow{2}{*}{$\begin{array}{l}\text { Mark } \\
\text { (JUS) }\end{array}$} & \multicolumn{4}{|c|}{ Soft annealing } & \multicolumn{5}{|c|}{ Tempering } \\
\hline & & $\begin{array}{l}\mathbf{t}, \\
{ }^{\circ} \mathrm{C}\end{array}$ & & $\begin{array}{c}\mathbf{H V}_{\mathrm{m}} \\
\mathrm{ax}\end{array}$ & $\begin{array}{c}\mathbf{R}_{\mathrm{m}} \\
\mathrm{MPa}\end{array}$ & $\begin{array}{l}\mathbf{t}, \\
{ }^{\circ} \mathrm{C}\end{array}$ & & & $\begin{array}{r}\mathbf{R}_{\mathrm{r}} \\
\mathbf{M I}\end{array}$ & \\
\hline 1. & Č5742 & $670-7$ & & 250 & 850 & $400-700$ & & & $1700-$ & 100 \\
\hline 2. & $\check{C} 4451$ & $800-8$ & & 250 & 850 & $550-700$ & & & $1700-$ & 100 \\
\hline
\end{tabular}

The hardness measured on selected samples (post heat treatment) was 40-42 HRC for C 5742 and 41-49 HRC for Č5741. The soft annealing was not performed (though HV > 350) since mechanical processing was mainly done by grinding. Because the HF samples of thicker cross-sections ( $\mathrm{s}=40-45 \mathrm{~mm}$ ) were made of steels prone to self-hardening, it was necessary to preheat the samples at a temperature calculated according to Seferian's formula, and it was $\mathrm{T}_{\mathrm{p}} \approx 300^{\circ} \mathrm{C}$.

\section{Welding procedure and parameters}

Technological parameters of HF were determined according to (EBARA R. and KUBOTA K. 2008, LAVTAR L. et al. 2005) what implied layers deposition in three passes, in order to reduce the degree of mixing (dilution). The HF speed of each pass was measured with Tastotherm D120 (with NiCr-NiAl thermocouple and measurements range of -50 to $1200{ }^{\circ} \mathrm{C}$ ). As the $\mathrm{FM}$ is used the high alloyed rutile electrodes UTOP 38 (DIN 8555 E3-UM-40T Ø3.25 mm) and UTOP 55 (DIN 8555 E6-UM-60T $\varnothing 5.00 \mathrm{~mm})$. Hardness of those FM's is stable up to a temperature of $600{ }^{\circ} \mathrm{C}$. Prior to HF, rutile electrodes were dried at $350-400{ }^{\circ} \mathrm{C}$. In Tables 3 and 4 HF parameters and the FM properties are presented, respectively. The HF layer deposition order is shown in Figure 1. The width of the pass deposited by the electrode with $\varnothing 3.25 \mathrm{~mm}$ was $\mathrm{b} \approx 10-12 \mathrm{~mm}$, the height was $\mathrm{h} \approx 1.5 \mathrm{~mm}$; and by the electrode $\varnothing 5.00 \mathrm{~mm}$ it was $\mathrm{b} \approx 10-12 \mathrm{~mm}$ and $\mathrm{h} \approx 2.1 \mathrm{~mm}$. (LAZIĆ V. et al. 2011).

Table 3. Hard facing parameters for the MMAW procedure and properties of used filler metals

\begin{tabular}{|c|c|c|c|}
\hline \multirow{3}{*}{\multicolumn{2}{|c|}{ MMAW properties }} & Ele & lark \\
\hline & & Steel plant ' & "/DIN 8555 \\
\hline & & UTOP 38 & UTOP 55 \\
\hline \multicolumn{2}{|l|}{ Core diameter, $\mathbf{m m}$} & 3.25 & 5.00 \\
\hline \multicolumn{2}{|l|}{ Welding current, $\mathrm{A}$} & 115 & 190 \\
\hline \multicolumn{2}{|l|}{ Current type } & $=(+)$ & $=(+)$ \\
\hline \multicolumn{2}{|l|}{ Voltage, $\mathrm{V}$} & 26 & 29 \\
\hline \multicolumn{2}{|l|}{ Welding speed, $\mathrm{mm} / \mathrm{s}$} & $\approx 2.8$ & $\approx 2.5$ \\
\hline \multicolumn{2}{|c|}{ Driving energy, $\mathrm{J} / \mathrm{mm}$} & 854.3 & 1763.2 \\
\hline \multicolumn{4}{|c|}{ Filler metal properties } \\
\hline \multirow{5}{*}{$\begin{array}{c}\text { Chemical } \\
\text { composition, \% }\end{array}$} & $\mathbf{C}$ & 0.13 & 0.50 \\
\hline & $\mathbf{C r}$ & 5.0 & 5.0 \\
\hline & Mo & 4.0 & 5.0 \\
\hline & $\mathbf{V}$ & 0.20 & 0.60 \\
\hline & $\mathbf{W}$ & in traces & in traces \\
\hline \multicolumn{2}{|c|}{ Hardness, HRC } & $36-42$ & $55-60$ \\
\hline
\end{tabular}
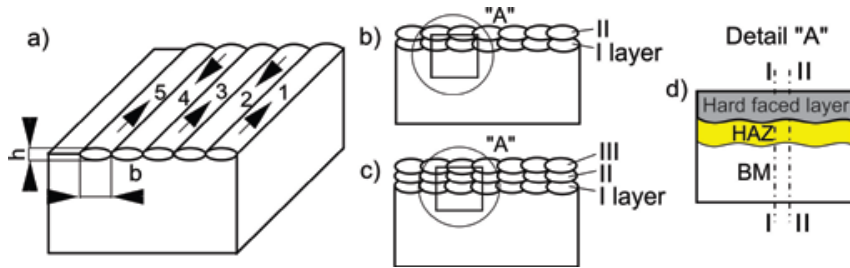

Fig. 1. Layers deposition order: $a-$ layer $1, b-2, c-3$, $d$-metallographic ground sample.

\section{Estimate of weldability based on the CCT diagrams}

It is of decisive importance to relate the useful inputoutput properties of the HF layer to applied technology and to establish the newly created structure and hardness in the HAZ. Thus, it is useful to know the corresponding Continuous Cooling Transformation (CCT) diagrams. They can be applied for an estimate of weldability of steels with similar chemical composition. To be able to apply them, one needs to know the cooling time within temperature range 800 to $500{ }^{\circ} \mathrm{C}\left(\mathrm{t}_{8 / 5}\right)$ for points beneath the HF layer. That time can be calculated by application of corresponding analytical expressions (LAVTAR L. et al. 2005, LAZIĆ V. et al. 2014), or obtained experimentally - by recording the temperature cycle at a certain point beneath the HF layer. By entering the calculated $t_{8 / 5}$ time into the corresponding CCT diagram, the newly created structure was estimated and the hardness red-off the diagram, Figure 2. This steel is very prone to self-hardening $(\mathrm{C}>0.35)$ and sensitive to heat input. Besides the high carbon content, it has a high content of alloying elements (Cr, Mo, V), which causes 
separation of perlite and bainite transformation, extend the austenite stability and lower the initial temperature of martensitic transformation.

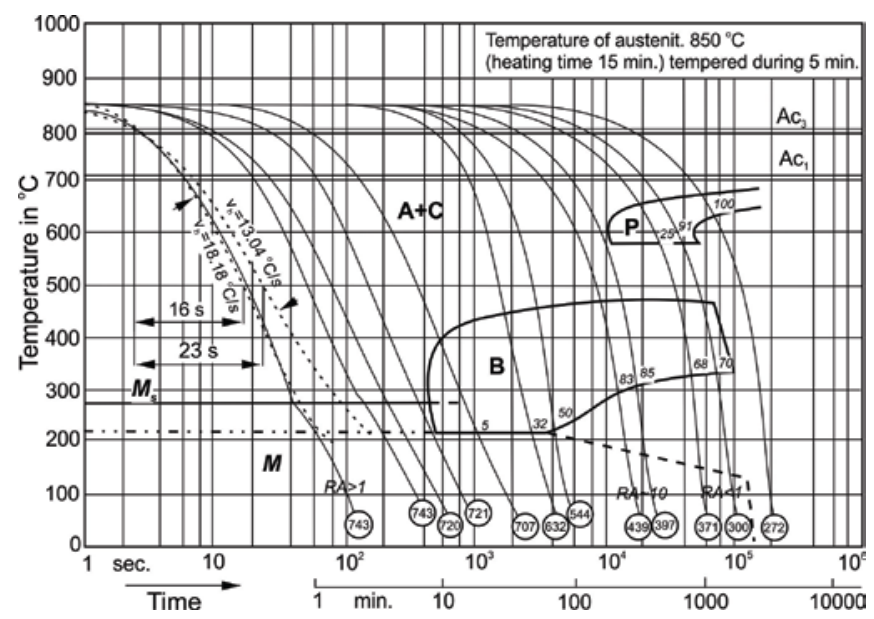

Fig. 2. CCT diagram for $\check{C} 5742$ steel.

\section{Determination of temperature cycles in hard facing of Č5742 steel}

In order to determine the cooling speed as precisely as possible, in HF of steel for forging dies, special model plates were prepared according to Figure 3. Plates were tempered and holes for measuring the temperature cycles were ground into them. According to official methods for estimates of weldability (LAZIĆ V. et al. 2011, MUTAVDŽIĆ M. et al 2008, 2012) this steel must be preheated, the suitable HF technology and additional heat treatment must be applied, to decrease the level of residual stresses in the HF piece. By recording the temperature cycle during the HF, it is possible to readoff the $t_{8 / 5}$ time. Besides experimentally, the $t_{8 / 5}$ time was also determined theoretically, by the Dziubinski Klimpel formula (DZIUBINSKI J. and KLIMPEL A. 1985), the Ito - Bessyo formula (ITO Y. and BEsSYO K. 1972) and the Rikalin's expressions (LAZIĆ V. et al. 2014). Calculated and experimentally obtained values are presented in Table 5 .

By entering the experimentally obtained cooling times into the CCT diagram, the newly created structure and the HAZ hardness were estimated. From Figure 2 one can notice that the limiting time $t_{8 / 5}=t_{100}$ is within range 500 to $1500 \mathrm{~s}$. That cooling time cannot be obtained by the MAG procedure, which implies that regardless of the HF parameters, one always obtains martensitic-carbide structure of the HAZ, with hardness $721-743 \mathrm{HV}$. Due to this, it is necessary to perform the tempering, to decrease the HAZ hardness and to increase plasticity in individual HF layer's zones.

\section{Hardness and microstructure testing}

To measure hardness and investigate newly created structures, the metallographic samples were prepared by grinding, obtained in various HF conditions. The thickness was varied ( $\mathrm{s}=7.4 \mathrm{~mm}$ and $29 \mathrm{~mm}$ ), as well as the type of FM and its diameter - the technology and parameters of the HF procedure. Samples were cooled in fireclay powder, and prior to metallographic tests, they were annealed at $340{ }^{\circ} \mathrm{C}$ and then slowly cooled to reduce the residual stress level. The hardness distribution diagram for one sample is presented in Figure 4. The sample was preheated to $300^{\circ} \mathrm{C}$ and after the HF it was tempered at $340{ }^{\circ} \mathrm{C}$. From a comparison of experimentally obtained results to those from the CCT diagrams the high correlation between the input and output characteristics can be observed.

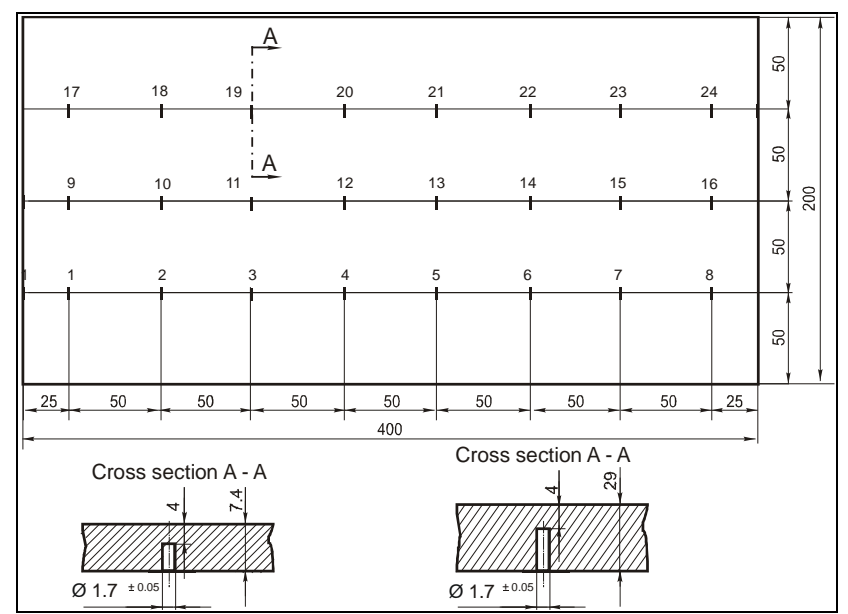

Fig. 3. Appearance of plates prepared for measuring the temperature cycles.

Table 5. Comparative values of the cooling time $t_{8 / 5}$.

\begin{tabular}{cccccc}
\hline $\begin{array}{c}\text { Thickness, } \\
\text { mm }\end{array}$ & $\left(\mathrm{t}_{8 / 5}\right)^{\mathbf{J}}$ & $\left(\mathrm{t}_{8 / 5}\right)^{\mathrm{Sgr}}$ & $\left(\mathrm{t}_{8 / 5}\right)^{\mathbf{E X P}}$ & $\left(\mathrm{t}_{8 / 5}\right)^{\mathbf{R}}$ & $\begin{array}{c}\text { Point/ } \\
\text { Layer }\end{array}$ \\
\hline \multirow{3}{*}{7.4} & 22.8 & 100.3 & 23.0 & $48-54$ & $11 / 1$ \\
& 20.1 & 84.9 & 27.0 & $42-50$ & $18 / 1$ \\
& 18.2 & 73.4 & 19.5 & $36-43$ & $3 / 1$ \\
\hline \multirow{2}{*}{29} & 76.2 & 287.5 & 78.0 & $70.5-74$ & $16 / 1$ \\
& 24.4 & 47.30 & 25.0 & $24-27$ & $14 / 1$ \\
& 10.4 & 14.89 & 12.0 & $13-14.5$ & $6 / 1$ \\
& 17.6 & 28.80 & 16.0 & $18-20$ & $13 / 1$ \\
& 20.2 & 37.10 & 20.5 & $21-23.5$ & $21 / 1$ \\
\hline
\end{tabular}

Based on experimental results, it was established that the calculated cooling time could be the most accurately determined by the Ito - Bessyo formula. Thus, the objective of this work was achieved, namely it was shown that the cooling speed could be accurately predicted without an expensive experiment. The sufficiently accurately determined cooling time enables reading off the structure and hardness from the CCT 
diagrams. Knowing the cooling time and the corresponding transformation diagrams for the considered steel, allows approximate determination of the optimal HF technology.

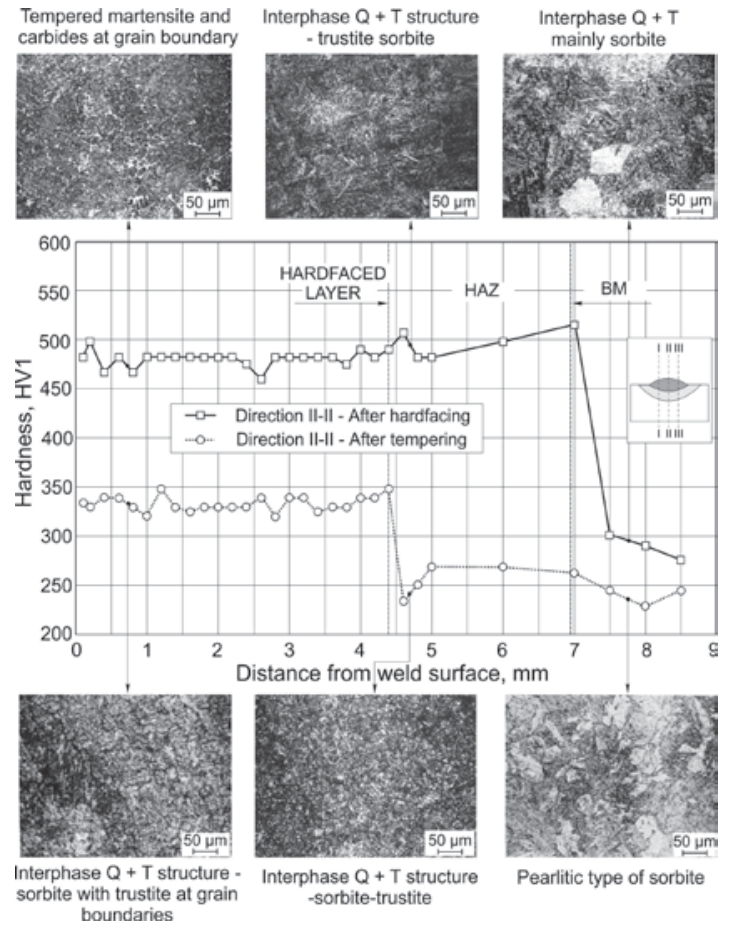

Fig. 4. Hardness distribution and microstructure of the HF layer zones (BM Č5742 - FM UTOP $38-s=7.4 \mathrm{~mm}$ ).

\section{Conclusion}

In this paper, the validity of detailed investigation of the forging dies reparation problems was demonstrated. Presented model investigations (as well as others, not presented here) show that the proposed reparation procedure on models and in real conditions can produce satisfactory results. Besides the requirements regarding good mechanical properties of the HF layer, wear resistance and thermal fatigue, the optimal toughness and favorable micro structure are requested, as well, namely the possibility for adequate machining. Those contradictory requirements could be met by proper selection of the reparation procedure and the adequate FM, application of preheating and additional heat treatment, as well as by selecting the optimal HF technology and final machining of the repaired tool.

\section{Acknowledgement}

This research was partially supported by European regional development fund and Slovak state budget by the project "Research Center of the University of Žilina" ITMS 26220220183 and by the Ministry of Education,
Science and Technological Development of Republic of Serbia through Grants: ON174004, TR32036 and TR35024.

\section{Literature}

1. АвАСH S., AKKOK M., GOKLER M.I. 2010 Wear analysis of hot forging dies. "Tribology International", 43, pp. 467473.

2. BRUCElle O., Bernhart G. 1999 Methodology for service life increase of hot forging tools. "Journal of Materials Processing Technology" 87, pp. 237-246.

3. ChOi C., Groseclose A., Altan T. 2012 Estimation of plastic deformation and abrasive wear in warm forging dies. "Journal of Materials Processing Technology" 212, pp. 1742-1752.

4. EBARA R. and KuBOtA K. 2008 Failure analysis of hot forging dies for automotive components. "Engineering Failure Analysis" 15, pp. 881-893.

5. Lavtar L. , Muhic T., Kugler G., Tercelu M. 2005 Analysis of the main types of damage on a pair of industrial dies for hot forging car steering mechanisms. "Engineering Failure Analysis" 18, pp. 1143-1152.

6. M. Kirchgassner, E. BADISCH, F. FraneK, 2008 Behaviour of iron-based hardfacing alloys under abrasion and impact, "Wear", 265/5-6, pp. 772-779

7. DZIUBINSKI J. and KLIMPEL A. 1985 Thermal surfacing and spraying, Wydawnictwa Naukowo - Techniczne. Warszawa. (In Polish)

8. ITO Y. and BESSYO K. 1972 Weld crackability formula of high strength steels, "Journal of Iron and Steel Institute" no. 13, pp. 916-930.

9. Summerville E., VenKatesan K., Subramanian C. 1995 Wear processes in hot forging press tools. "Materials and design" 16/ 5, pp. 289-294.

10. Marković S., Milović LJ., Marinković A., LAzović T., 2011 Tribological Aspect of Selecting Filler Metal for Repair Surfacing of Gears by Hard facing, "Structural Integrity and Life", 11, pp. 127-130.

11. LaziĆ V., M. MutavdžIĆ, D. MilosavljeviĆ, S. Aleksandrović, B. Nedeljković, P. Marinković, R. ČUKIĆ. 2011 Selection of the most appropriate technology of reparatory hard facing of working parts on universal construction machinery. "Tribology in Industry", 33/1, pp. 18-27.

12. Lazić V., IVANović I., SEDMAK A, Rudolf R., Lazić M., RADAKOVIĆ Y. 2013 Numerical Analysis of temperature field during hard facing process and comparison with experimental results. "Thermal science" 17/1, pp. S113S120.

13. MutAVDŽIĆ M., ČUKIĆ R., Jovanović M., MilosaVlJeVIĆ D., LAZIĆ V. 2008 Model investigations of the filler metals for regeneration of the damaged parts of the construction mechanization. "Tribology in Industry", 30/3, pp. 3-9.

14. MutaVdží́ M., LaziĆ V., MilosavljeVić D., ALEKSANDROVIĆ D., NiKOlić R., ČUKić R., BOGDANOviĆ G. 2012 Determination of the optimal tempering temperature in hard facing of the forging dies. "Materials Engineering" 19, pp. 95-103.

15. Thyssen Marathon Edelstahl - Vosendorf, Železarna Jesenice - Fiprom 2013 Catalogues and Prospects. 